\title{
PAWEL OCHMANN
}

Uniwersytet Jagielloński w Krakowie

JAKUB WOJAS

Europejski Instytut Studiów Międzynarodowych w Bytomiu

\section{Prawne aspekty konfliktu zbrojnego na Ukrainie jako przykład wojny hybrydowej ${ }^{1}$}

\section{The Legal Aspects of the Armed Conflict in Ukraine as an Example of a Hybrid War}

The term 'hybrid war' has not been defined in the public international law. However, it is commonly used in the media, by politicians and also by academics in scientific discourses.

The article raises the question of whether it is justified to use the term 'hybrid war' in reference to the military conflict in Ukraine. The authors scrutinise to what extent the situation in Ukraine meets the criteria of a 'hybrid war'. Therefore, they try to define the term and describe its distinctive characteristics. Then, successive developments in Ukraine are analysed and compared with the characteristics.

The article focuses on the role of the Dontsk People's Republic and Luhansk People's Republic, and their dependence on the Russian Federation. According to the authors, they are examples of actions conducted by proxies - the so called proxy war. This is the most important proof of the hybrid nature of the conflict in Ukraine. The authors also consider the responsibility of Russia for the actions of these separatist republics and wonder how to prevent the consequences of this conflict.

Keywords: hybrid war, proxy war, international public law, military conflict, Ukraine.

1 Praca naukowa finansowana ze środków budżetowych na naukę w roku 2017 jako projekt badawczy w ramach programu MNiSW „Diamentowy Grant” prowadzony na Uniwersytecie Jagiellońskim pod kierownictwem Pawła Ochmanna pt. „Wojny hybrydowe i ich implikacje dla postzimnowojennego ładu międzynarodowego". 


\section{Wprowadzenie}

Od czasu agresji ${ }^{2}$ rosyjskiej na Krym, a następnie na Donbas zarówno w mediach, jak i w dyskursie naukowym i debacie publicznej na całym świecie niezwykle popularne stało się określenie ,wojna hybrydowa”. Pojęcie to znalazło się pośród głównych terminów stosowanych do opisu konfliktu na Ukrainie i jest używane obecnie nie tylko przez dziennikarzy, ale też czołowych polityków na całym świecie ${ }^{3}$.

Celem artykułu jest próba zastanowienia się, na ile uprawnione jest posługiwanie się tym pojęciem w odniesieniu do toczącego się od lutego $2014 \mathrm{r}$. konfliktu zbrojnego na terytorium Ukrainy. Z tego względu w pracy poruszone zostaną kwestie związane z definicją wojny hybrydowej. Wskazane zostaną także cechy tego typu konfliktów zbrojnych, a następnie przeanalizowana wojna na Ukrainie pod kątem występowania wyróżnionych elementów konstytutywnych.

Szczególny nacisk położono na aspekty związane z funkcjonowaniem Donieckiej Republiki Ludowej (DRL) oraz Ługańskiej Republiki Ludowej (ŁRL) i ich zależności od Federacji Rosyjskiej. Zdaniem autorów można je poczytywać za jedne z modelowych przykładów działania agresora przez pośrednika (proxy war), a przez to za najważniejszy dowód świadczący o hybrydowości konfliktu na Ukrainie. W tym miejscu omówione zostaną kwestie związane z przypisaniem Rosji odpowiedzialności za działania tych samozwańczych republik wraz z analizą, na ile jest możliwe uniknięcie szkodliwych skutków związanych z hybrydowością tego konfliktu.

2 O tym, czy rosyjskie działania na Półwyspie Krymskim można uznać za agresję w rozumieniu prawa międzynarodowego zob. P. Ochmann, J. Wojas, Wspótczesne znaczenie aktu wypowiedzenia wojny w kontekście konfliktu na wschodzie Ukrainy, „Sprawy Międzynarodowe" 2015, nr 4, s. 93 i nast.

3 Z polskich polityków tym określeniem w odniesieniu do konfliktu na Ukrainie posługiwali się, m.in. Donald Tusk, Radosław Sikorski czy Tomasz Siemoniak. Za: J. Regina-Zacharski, Ukraina 2014-2015: wojna (nie)hybrydowa, „Zeszyty Naukowe AON” 2015, nr 3, s. 32; ,wojna hybrydowa” w stosunku do tego konfliktu pojawiła się też w rezolucji Parlamentu Europejskiego: European Parliament resolution of 15 January 2015 on the situation in Ukraine [2014/2965(RSP)]; z zagranicznych polityków pojęcia tego użyli m.in. brytyjska premier Theresa May, www.newsweek.com/ukraine-was-putinstesting-ground-his-hybrid-war-west-716857; niemiecka minister obrony Ursula von der Leyen, www.newsweek.com/ukraine-was-putins-testing-ground-his-hybrid-warwest-716857 czy też niemiecki minister spraw zagranicznych Frank-Walter Steinmeier (dostęp: 5.04.2018). 


\section{Niejednoznaczność i pojemność pojęcia wojny hybrydowej}

Wyrażenie „wojna”, choć już od wieluset lat pojawiało się w aktach prawnych, to do tej pory nie doczekało się jeszcze legalnej definicji. Po II wojnie światowej wyraźna była tendencja do odchodzenia od pojęcia wojny na rzecz pojęcia konfliktu zbrojnego. Powodem tego było unikanie przez wiele państw określania mianem ,wojny” swoich działań zbrojnych skierowanych przeciwko innym krajom. Takie postępowanie miało, ich zdaniem, uchronić przed zarzutami naruszenia zasad prawa wojennego i ewentualnymi negatywnymi reakcjami ze strony społeczności międzynarodowej ${ }^{4}$. Obecnie można stwierdzić, że w prawie międzynarodowym określenie mianem wojny starć między co najmniej dwoma podmiotami prawa międzynarodowego jest irrelewantne. Od aspektów semantycznych zdecydowanie większe znaczenie ma legalność podejmowanych działań zbrojnych, a ta w znacznej mierze zależy od powodów ich podjęcia ${ }^{5}$.

Pojęcie wojny jest $\mathrm{z}$ kolei definiowane przez badaczy stosunków międzynarodowych ${ }^{6}$, tudzież centra analiz, jak Sztokholmski Instytut Badań nad Pokojem (SIBP, ang. SIPRI) ${ }^{7}$. W definicji opracowanej przez ten ośrodek kryterium, które pozwala nam określić dane wydarzenia mianem „wojny", jest liczba ofiar. Wynosi ona 25 osób w ciągu roku ${ }^{8}$. SIPRI uprościł definicję wypracowaną przez inny znamienity szwedzki ośrodek naukowy - uniwersytet w Uppsali. W ramach Uppsala Conflict Data Project (UCDP) sformułowano podziały konfliktów zbrojnych na podstawie kryterium intensywności, którego miernikiem jest liczba zabitych $\mathrm{w}$ ciągu roku. W ramach tego podziału wyróżnia się mniejszy konflikt (minor, poniżej

4 Przyjmuje się, że od 1954 r., czyli momentu przyjęcia konwencji haskiej o ochronie dóbr kulturalnych, w razie konfliktu zbrojnego określenie ,wojna” zostało w prawie międzynarodowym już z powodzeniem wyparte przez „konflikt zbrojny”. Zob. R. Bierzanek, J. Symonides, Prawo międzynarodowe publiczne, Wydawnictwo Prawnicze LexisNexis, Warszawa 2004, s. 379.

5 Jest to przede wszystkim związane z przyjęciem Karty Narodów Zjednoczonych z 1945 r., w której znalazł się w art. 2 (4) zakaz użycia siły.

6 Zob. np. J. Regina-Zacharski, Analityczne definicje wojny, ,Studia Geopolitica”, 2010/2011, R. 1, tekst dostępny także na http://geopolityka.org/analizy/jacek-reginia-zacharskianalityczne-definicje-wojny (dostęp: 5.04.2018).

7 Counted as battle-related is conflict behavior between warring parties in the conflict dyad, which is directly related to the incompatibility, i.e. carried out with the purpose of realizing the goal of the incompatibility and results in deaths. Zob. www.pcr.uu.se/ research/UCDP/data_and_publications/definitions_all.htm (dostęp: 5.04.2018). www.sipri.org/yearbook/2013/01 (dostęp: 5.04.2018). 
25 zabitych), średni (intermediate, między 25-1000 zabitych) oraz wojnę (powyżej 1000 zabitych).

O wiele większe problemy definicyjne budzi określenie „hybrydowości” wojny. W literaturze anglojęzycznej można wskazać dwie najczęściej przywoływane definicje wojny hybrydowej. W. Williamson Murray i P.R. Mansoor w swojej pracy poświęconej historii wojen hybrydowych definiują wojnę hybrydową jako „konflikt obejmujący użycie regularnych sił zbrojnych i oddziałów nieregularnych (o charakterze partyzanckim, powstańczym lub terrorystycznym), w którym uczestniczyć mogą państwo bądź aktor niepaństwowy, a ich działania skupiają się na osiągnięciu spójnego politycznego celu"lo.

W tym miejscu należy wskazać na kilka kluczowych elementów, a mianowicie występowanie obok siebie oddziałów regularnych i nieregularnych oraz istnienie spójnego celu politycznego. Natomiast status prawny strony (państwo/aktor niepaństwowy) ma tutaj drugorzędne znaczenie.

Nietrudno się zatem domyślić, że takie przedstawienie tego zagadnienia może spowodować, iż pojęcie wojny hybrydowej będzie obejmować większość konfliktów zbrojnych. Działanie obok siebie oddziałów regularnych i nieregularnych w imię spójnego celu politycznego występowało przecież już od czasów starożytnych. Kwestie określenia statusu prawnego grup, które w obliczu napaści spontanicznie chwyciły za broń, uregulowano już w regulaminie haskim z 1907 r. ${ }^{11}$ Inną definicję wojny hybrydowej proponuje F.G. Hoffman. Według niego w konfliktach tego typu przynajmniej jedna ze stron „równolegle stosuje unikalne połączenie użycia broni konwencjonalnej, nieregularnej taktyki działania, terroryzmu i działań o charakterze kryminalnym w ramach realizacji celów politycznych" ${ }^{\prime 2}$. Pierwszym konfliktem zbrojnym, który szeroko rozpatrywano pod tym kątem, była tzw. wojna lipcowa z 2006 r. między Hezbollahem a Izraelem ${ }^{13}$. Hoffman wskazywał, że podczas tego starcia

9 Zob. wydany wspólnie przez UCDP wraz z Norweskim Instytutem Badań nad Pokojem (Peace Research Institute Oslo PRIO) www.prio.org/Global/upload/CSCW/Data/ UCDP/2009/Codebook_UCDP_PRIO Armed Conflict Dataset v4_2009.pdf (dostęp: 5.04.2018).

10 M. Willisamson Murray, P.R. Mansoor, Hybrid Warfare: Fighting Complex Opponets from the Ancient World to the Present, Cambridge University Press, Cambridge 2012, s. 2.

11 Konwencja dotycząca praw i zwyczajów wojny lądowej, Dz.U. z 1927 r., nr 21, poz. 161.

12 F.G. Hoffman, Conflict in the 21st Century: The Rise of Hybrid Wars, Potomac Institute for Policy Studies, Arlington, VA 2007, s. 28; F.G. Hoffman, On Not-So-New Warfare: Politicale Warfare vs. Hybrid Threats, https://warontherocks.com/2014/07/on-not-sonew-warfare-political-warfare-vs-hybrid-threats/ (dostęp: 5.04.2018).

13 F.G. Hoffman, Lessons from Lebanon: Hezbollah and Hybrid Wars, Foreign Policy Research Institute, www.fpri.org/article/2006/08/lessons-from-lebanon-hezbollah-andhybrid-wars (dostęp: 5.04.2018). 
można było zaobserwować takie elementy hybrydowe, jak walka podmiotu pozapaństwowego z państwem, przy wykorzystaniu potężnej machiny informacyjno-propagandowej, działań terrorystycznych i dywersyjnych oraz nowoczesnego sprzętu. Ponadto badacz ten uznał wojnę hybrydową za wyjątkowo skuteczny sposób walki ${ }^{14}$, choć, jak wskazują inni autorzy, trudno ją uznać za coś nowego ${ }^{15}$. Już w VI w. p.n.e. chiński strateg Sun Tzu postulował dążenie do osiągnięcia zamierzonych w wojnie celów, przy ponoszeniu przy tym jak najmniejszych strat, poprzez wykorzystanie takich metod, jak podstęp wojenny, działania wywiadowcze i z zaskoczenia oraz działania, których celem było złamanie woli walki przeciwnika ${ }^{16}$. Jako starożytny przykład wojny hybrydowej często wskazuje się wojnę peloponeską (431-404 p.n.e.) ${ }^{17}$.

Według M. Willisamsona Murraya i P.R. Mansora szczególnie ważnym elementem wojny hybrydowej jest kombinacja konwencjonalnych sił wojskowych oraz sił nieregularnych (partyzantów, rebeliantów lub terrorystów) ${ }^{18}$. Należy również zwrócić uwagę na częste przeprowadzanie w czasie wojen hybrydowych operacji specjalnych, dokonywanych na tyłach przeciwnika, a także wzmożoną aktywność propagandową czy przeprowadzanie ataków cybernetycznych.

Inną charakterystyczną cechą jest swoiste ,rozmycie” między stanem pokoju a stanem wojny. Wynika to z prowadzenia przez strony konfliktu tzw. aktywności poniżej progu wojny (below the threshold of war). Przyczyną tego może być wspomniana stała tendencja państw do unikania odpowiedzialności za prowadzenie wojny. $Z$ tego też względu w trakcie wojen hybrydowych strony mogą działać przez swoich pośredników (proxy war), głównie aktorów niepaństwowych, nad którymi właściwa strona konfliktu sprawuje zakamuflowaną kontrolę ${ }^{19}$.

Kolejną cechą wojen hybrydowych jest ich zmienna intensywność. Niekiedy tego typu konflikty przechodzą do stanu zamrożenia, by po jakimś czasie znów przybrać na sile. Mogą występować też sytuacje, gdy działanie poniżej progu wojny powoduje, że konflikt przybiera formę pełzającą, rozciągniętą w czasie, charakteryzującą się ciągłą obawą opinii publicznej przed wybuchem ,pełnowymiarowego konfliktu”.

14 Ibidem.

$15 \mathrm{~K}$. Wąsowski, Istota i uniwersalność rosyjskiego modelu wojny hybrydowej, „Sprawy Międzynarodowe" 2015, nr 2, s. 40.

16 Sun Tzu, Sun Pin, Sztuka wojny, tłum. D. Bakalarz, Helion, Gliwice 2004, s. 60-62 i nast.; J. Regina-Zacharski, Ukraina 2014-2015, s. 34-35.

17 K. Wąsowski, Istota i uniwersalność..., s. 40.

18 M. Willisamson Murray, P.R. Mansoor, Hybrid Warfare, s. 2.

19 K. Wąsowski, Istota i uniwersalnośćc..., s. 42-43. 
Wymienione cechy powodują, że definicja wojny hybrydowej jest na tyle pojemna, że może w sobie zawierać także inne, znane w dziedzinie stosunków międzynarodowych, rodzaje konfliktów zbrojnych. Należy do nich konflikt asymetryczny, z którym mamy do czynienia w momencie, gdy ścierają się strony są o różnym potencjale, gdy strona słabsza wykorzystuje działania o charakterze niekonwencjonalnym, terrorystycznym, niezgodne z przyjętymi zasadami prowadzenie konfliktu zbrojnego, na co nie może sobie pozwolić strona silniejsza ${ }^{20}$.

Wojna hybrydowa może także w sobie zawierać konflikt nieregularny, w którym jedna ze stron jest aktorem niepaństwowym. Innym pojęciem jest wojna mieszana, czyli wykorzystanie w jedynym konflikcie przez co najmniej jedną stronę jednocześnie oddziałów regularnych i nieregularnych ${ }^{21}$.

Warto również przywołać postać, której dorobek wskazuje się jako inspirację dla podjętych przez Rosję działań na Ukrainie. Jest to Jewgienij Messner - dawny pułkownik armii białej Rosji, który w latach 60. XX w. stworzył pojęcie „wojen buntowniczych”. Jest ono niemal bliźniaczo podobne do omawianej tu wojny hybrydowej. Zdaniem tego badacza w trakcie wojny buntowniczej także dochodzi do stanu rozmycia między pokojem a wojną. Messner podkreślał jednakże wagę wojny informacyjnej jako cennego czynnika do destabilizacji społeczeństwa. Wskazywał również, że poszczególne grupy społeczne mogą zaangażować się bezpośrednio w konflikt, co może doprowadzić do zatarcia się granicy między przedstawicielami sił zbrojnych a cywilami. Ze zjawiska unikania przez państwa bezpośredniego zaangażowania w konflikt wysnuwał wniosek, że może to doprowadzić do niejednoznaczności między tym, co legalne, a tym, co bezprawne ${ }^{22}$.

\section{Wojna na Ukrainie}

Za początek wojny na Ukrainie przyjmuje się 23 lutego 2014 r., czyli moment pojawienia się na Półwyspie Krymskim grup żołnierzy w mundurach bez oznaczeń, nazywanych zielonymi ludzikami ${ }^{23}$. Przez nieco ponad mie-

20 A. Kleczkowska, Wojna hybrydowa - uwagi z perspektywy prawa międzynarodowego publicznego, „Sprawy Międzynarodowe” 2015, nr 2, s. 98.

21 Ibidem.

22 J.E. Miesnier, Wsiemirnaja miatieżewojna, Żukowskij-Moskwa 2004, s. 100-150; K. Kraj, Wojny asymetryczne czy miatieżewojna Jewgienija Messnera zagrożeniem dla bezpieczeństwa w XXI wieku, „Bezpieczeństwo. Teoria i Praktyka” 2012, nr 3, s. 33-39; L. Sykulski, Wojny buntownicze - wprowadzenie do koncepcji Jewgienija Messnera, „Przegląd Geopolityczny” 2015, nr 11, s. 103-111.

23 T. Srogosz, Status prawny nieoznakowanych żolnierzy w wojnie hybrydowej, „Sprawy Międzynarodowe" 2015, nr 4, s. 79. 
siąc niemal bezkrwawo zajmowali oni bazy armii ukraińskiej i strategiczne punkty na półwyspie. Podczas tego etapu konfliktu nie doszło do starć zbrojnych, a wojska ukraińskie zostały ewakuowane z Krymu ${ }^{24}$.

Zupełnie inaczej przebiegły wydarzenia na Donbasie. Tam, w kwietniu, po miesiącu społecznych protestów, uzbrojone grupy zaczęły zajmować budynki administracji. Reakcja władz w Kijowie była już tu bardziej zdecydowana niż w przypadku kryzysu krymskiego. Jeszcze w tym samym miesiącu doszło do pierwszych starć zbrojnych. Przybrały one na sile w szczególności latem 2014 r. W połowie sierpnia regularne jednostki sił zbrojnych Federacji Rosyjskiej przekroczyły granicę z Ukrainą, walnie przyczyniając się tym samym do załamania sił rządowych ${ }^{25}$.

Na części obwodu donieckiego i ługańskiego istniały już wówczas dwie samozwańcze republiki ludowe. Po rokowaniach międzynarodowych z udziałem przedstawicieli Niemiec, Francji, Rosji i Ukrainy i zawarciu 5 września 2014 r. porozumienia nazwanego Mińsk I, na przełomie września i października zmniejszyła się intensywność starć. Zacięte walki trwały jednak nadal w określonych punktach frontu, jak np. donieckie lotnisko czy okolice miasta Debalcewe. Po kolejnej intensyfikacji starć, 12 lutego 2015 r. doszło do zawarcia umowy Mińsk II. Po kilku dniach od tego wydarzenia wstrzymano działania ofensywne sił prorosyjskich i konflikt wszedł w trwającą do dziś fazę wojny pozycyjnej ${ }^{26}$. Obecnie tygodniowo ginie na froncie od kilku do kilkunastu żołnierzy ukraińskich ${ }^{27}$.

\section{Hybrydowość wojny na Ukrainie}

Biorąc pod uwagę wskazane wcześniej elementy, składające się na pojęcie wojny hybrydowej, w pierwszej kolejności należy zwrócić uwagę na wysoki stopień skomplikowania tego konfliktu, który ewidentnie wskazuje na chęć ukrycia przez Rosję faktu swojego zaangażowania. Już w trakcie kryzysu krymskiego

24 K. Kubiak, RAPORT-wto 04/2014 - Utrata Krymu, Raport Wojsko - Technika - Obronność, www.altair.com.pl/magazines/article?article_id=5150 (dostęp: 5.04.2018).

25 M. Menkiszak, R. Sadowski, P. Żochowski, Rosyjska interwencja zbrojna we wschodniej Ukrainie, Ośrodek Studiów Wschodnich, www.osw.waw.pl/pl/publikacje/analizy/ 2014-09-03/rosyjska-interwencja-zbrojna-we-wschodniej-ukrainie (dostęp: 5.04.2018).

26 A. Wilk, T.A. Olszański, W. Górecki, Porozumienie mińskie - rok gry pozorów, www. osw.waw.pl/pl/publikacje/analizy/2016-02-10/porozumienie-minskie-rok-gry-pozorow (dostęp: 5.04.2018).

27 Od 23 do 29 października 2017 zginęło na Donbasie 5 ukraińskich żołnierzy. W następnym tygodniu liczba zabitych po stronie ukraińskiej wynosiła 2. www.unian.info/war (dostęp: 5.04.2018). 
Rosjanie użyli podstępu, aby ukryć przed przeciwnikiem i społecznością międzynarodową swoje rzeczywiste intencje. Półwysep przejęli żołnierze w mundurach bez oznaczeń, którzy oficjalnie zaprzeczali swojej przynależności do Sił Zbrojnych Federacji Rosyjskiej. Podawali się przy tym za oddziały Samoobrony Krymu, czyli rzeczywiście istniejące lokalne grupy cywilów popierających przyłączenie półwyspu do Rosji. Powodowało to naturalną dezorientację władz w Kijowie, a w konsekwencji brak reakcji na rosyjskie poczynania.

W tym kontekście należy wskazać na czynnik, który jeszcze dodatkowo paraliżował decyzyjność ukraińskich decydentów. Była to obawa przed ,pełnowymiarowym konfliktem", czyli przejście przez Rosję do działań charakterystycznych dla wojen konwencjonalnych, jak masowe bombardowania czy ataki dużych jednostek ${ }^{28}$.

Operacja krymska była również wzmocniona aspektem propagandowo-informacyjnym. Na obszarze Krymu ograniczono dostęp do mediów ukraińskich, z kolei media rosyjskie informowały o chaosie i „faszystowskich” rządach, jakie zapanowały w Kijowie po zwycięstwie rewolucji godności ${ }^{29}$.

W przypadku starć na Donbasie można zaobserwować niemal identyczne działania. Aspekt propagandowo-informacyjny przyczynił się wydatnie do skłonienia tamtejszej ludności do wywołania czegoś w rodzaju powstania antyukraińskiego. Z kolei grupy biorące udział w tych działaniach były niejednokrotnie organizowane przez funkcjonariuszy rosyjskich służb specjalnych ${ }^{30}$. Warto tutaj przypomnieć, że doprowadzanie do napięć społecznych w kraju przeciwnika było jedną z głównych cech wojen buntowniczych według J. Messnera.

Jednocześnie, walki na Donbasie w pewnych elementach zasadniczo różniły się od działań na Krymie. Po zakończeniu kryzysu krymskiego Rosja oficjalnie przyznała, że ,zielone ludziki” były w rzeczywistości rosyjskimi żołnierzami ${ }^{31}$. Wypuściła też ukraińskich jeńców, nie dokonywała na terytorium

28 Dramatyczny stenogram ws. Krymu. „, My ich wyślemy na śmierć”, Wirtualna Polska, https://wiadomosci.wp.pl/dramatyczny-stenogram-ws-krymu-my-ich-wyslemy-nasmierc-6025262095110785a (dostęp: 5.04.2018).

29 Media freedom situation in Crimea, Ukraine, at all-time low, OSCE Representative says, Organisation for Security and Co-operation in Europe, www.osce.org/fom/143861 (dostęp: 5.04.2018).

30 GPU obnarodovala zapisi telefonnyh razgovorov sovetnika prezidenta RF Glaz'eva otnositel'no plana „Novorossiâ”, 112ua, https://112.ua/glavnye-novosti/gpu-obnarodovala-zapisi-telefonnyh-razgovorov-sovetnika-prezidenta-rf-glazeva-otnositelno-plana-no vorossiya-333576.html (dostęp: 5.04.2018).

31 Tak stwierdził m.in. prezydent Władimir Putin 17 kwietnia 2014 r. Zob. Direct Line with Vladimir Putin, kremlin.ru, http://en.kremlin.ru/events/president/news/20796 (dostęp: 5.04.2018). 
półwyspu już żadnych wrogich aktów, a nawet wycofała swoje wojska z części obwodu chersońskiego zajętego podczas kryzysu ${ }^{32}$. Na Donbasie z kolei działania zbrojne podjęły nie ,zielone ludziki”, lecz lokalne bojówki, które stały się częścią sił zbrojnych DRL i ŁRL ${ }^{33}$. Wojna na Ukrainie przeszła tym samym w fazę wojny przez pośrednika. Chociaż armia rosyjska niejednokrotnie brała jeszcze udział w walkach, były to już zazwyczaj siły wsparcia, które pojawiały się, gdy wojska separatystów po prostu przegrywały ${ }^{34}$.

Tym samym mamy tu elementy wojny mieszanej, gdy strona konfliktu wykorzystuje jednocześnie oddziały regularne i nieregularne. Można zaryzykować nawet stwierdzenie, że w pewnym momencie to właśnie oddziały nieregularne dominowały na froncie tej wojny. Ze strony prorosyjskiej są to przede wszystkim oddziały separatystów z DRL i ŁRL. Jednakże na początku konfliktu ciężar walk po stronie ukraińskiej opierał się również w znacznej mierze na oddziałach ochotniczych, nieregularnych, które dopiero z czasem były włączane pod auspicje władz w Kijowie. Obecnie taki nieregularny charakter mają bojówki skrajne prawicowej organizacji Prawy Sektor ${ }^{35}$.

W przypadku sił separatystycznych należy zwrócić uwagę na pewne aspekty, które można również uznać za elementy konfliktu hybrydowego. Prócz podległych rządom samozwańczych republik jednostek, przeciwko siłom ukraińskim walczą również oddziały lokalnych watażków, głównie Kozaków, którzy wykazywali się niejednokrotnie brakiem podporządkowania dowództwu separatystystów ${ }^{36}$. Ponadto działalność tych grup zbrojnych czę-

32 Ukraina: rossijskie vojska tak i ne ušli iz-pod Hersona, BCC News Russian http:// www.bbc.com/russian/international/2014/12/141210_russian_military_kherson (dostęp: 5.04.2018).

33 M. Gawęda, Siły Zbrojne „Noworosji”. W kierunku zwasalizowanej armii regularnej, Defence24, www.defence24.pl/185935, sily-zbrojne-noworosji-w-kierunku-zwasalizowanejarmii-regularnej (dostęp: 5.04.2018).

34 Przykładem tego są chociażby walki na początku 2015 r. Zob. W. Konończuk, A. Wilk, Eskalacja starć w Donbasie, Ośrodek Studiów Wschodnich, www.osw.waw.pl/pl/publikacje/analizy/2015-01-21/eskalacja-starc-w-donbasie (dostęp: 5.04.2018).

35 C. Kosior, Potencjat militarny Ukrainy $w$ obliczu rosyjskiej agresji, Ośrodek Analiz Strategicznych, https://oaspl.org/2015/06/23/potencjal-militarny-ukrainy-w-obliczurosyjskiej-agresji (dostęp: 5.04.2018).

36 Kozacy ogtaszaja nowa republike na wschodzie Ukrainy. Atakuja sity rzadowe, sa zabici $i$ ranni, „Gazeta Wyborcza”, http://wyborcza.pl/1,76842,16809315,Kozacy_oglaszaja_nowa_republike_na_wschodzie_Ukrainy_html; W „,_ugańskiej Republice Ludowej” narasta bunt. Apelują do Rosji, by „zrobiła porzadek”, TVN24, www.tvn24.pl/wiadomosci-ze-swiata,2/w-luganskiej-republice-ludowej-narasta-bunt-kozacy-apeluja-do-wladimi ra-putina,503690.html; Petna gotowość bojowa w ,,donieckiej republice”. Bunt Kozaków przyspieszy wojnę?, TVN24, www.tvn24.pl/wiadomosci-ze-swiata,2/donbas-mobilizacjarebeliantow-oddzialy-w-pelnej-gotowosci-bojowej,531592.html (dostęp: 5.04.2018).. 
sto ma też charakter kryminalny, co wszystko razem przyczynia się do jeszcze większej destabilizacji regionu i spotęgowania stanu chaosu ${ }^{37}$.

Dodać również należy pojawiające się podejrzenia o związek separatystów z przeprowadzanymi co jakiś czas na Ukrainie zamachami terrorystycznymi $^{38}$. Ukraina postulowała zresztą na arenie międzynarodowej o wpisanie DRL i ŁRL na listę organizacji terrorystycznych ${ }^{39}$. Natomiast sama operacja skierowana przeciwko separatystom nazywana jest na Ukrainie operacją antyterrorystyczną ${ }^{40}$.

Kolejnym ważnym elementem zaistniałym w czasie wojny na Donbasie jest stan rozmycia między wojną a pokojem. Przejawia się on w dwóch aspektach. Chociaż władze ukraińskie często wskazywały, że Rosja jest rzeczywistą stroną tej wojny, nie poszły za tym jednak żadne znane z wojen konwencjonalnych kroki prawne, jak zerwanie stosunków dyplomatycznych i gospodarczych. Długo też wstrzymywano się z oficjalnym określeniem Rosji jako agresora $^{41}$. Z kolei pojmanych żołnierzy separatystycznych czy nawet rosyjskich nie traktuje się zgodnie z obowiązującymi w trakcie międzynarodowego konfliktu zbrojnego jako jeńców, lecz są im stawiane zarzuty kryminalne ${ }^{42}$. Taka postawa jest poniekąd związana z obawą przed pełnowymiarowym konfliktem zbrojnym, czyli zaangażowaniem Rosji nie przez pośredników, lecz

37 T. Piechal, Republiki wojenne w Donbasie rok po wybuchu konfliktu, Ośrodek Studiów Wschodnich, www.osw.waw.pl/pl/publikacje/komentarze-osw/2015-06-17/republikiwojenne-w-donbasie-rok-po-wybuchu-konfliktu (dostęp: 5.04.2018).

38 Prorosyjscy separatyści odpowiadają najprawdopodobniej m.in. za zestrzelenie 17 lipca 2014 r. malezyjskiego samolotu pasażerskiego lotu MH17 i ostrzelanie cywilnego autobusu w Wołnowasze 13 stycznia $2015 \mathrm{r}$.

39 M. Mikulska, Separatystyczne republiki na Ukrainie uznane za organizacje terrorystyczne, „Rzeczpospolita”, www.rp.pl/artykul/1110516-Separatystyczne-republiki-na-U krainie-uznane-za-organizacje-terrorystyczne.html; Ukraina apeluje o uznanie separatystycznych republik za organizacje terrorystyczne, Telewizja Republika, http://telewizjarepublika.pl/ukraina-apeluje-o-uznanie-separatystycznych-republik-za-organizacjeterrorystyczne, 15952.html (dostęp: 5.04.2018).

40 A. Wilk, Ukraińska operacja antyterrorystyczna w Kramatorsku i Stowiańsku - gra pozorów?, Ośrodek Studiów Wschodnich, www.osw.waw.pl/pl/publikacje/analizy/2014-05-08/ukrainska-operacja-antyterrorystyczna-w-kramatorsku-i-slowiansku-gra (dostęp: 5.04.2018).

41 Oficjalnie nastąpiło to dopiero 6 października 2017 r.; Parlament Ukrainy uchwalit ustawę o reintegracji Donbasu. ,, Rosja agresorem”, bankier.pl, www.bankier.pl/wiadomosc/ Parlament-Ukrainy-uchwalil-ustawe-o-reintegracji-Donbasu-Rosja-agresorem-4016852. html (dostęp: 5.04.2018).

$42 \mathrm{~W}$ praktyce obecnie na skutek porozumień mińskich pojmani separatyści często nie stają przed sądem, ale są po pewnym czasie wymieniani na schwytanych przez rebeliantów żołnierzy ukraińskich. Zob. W. Burlakowa, Nestrašnyj sud. Kak ukrainskaâ Femida 'karaet' separatistov, Antikor, http://antikor.com.ua/articles/68825-nestrashnyj_sud._kak_ ukrainskaja_femida_karaet_separatistov (dostęp: 5.04.2018). 
przy wykorzystaniu w pełni swoich zasobów. W przypadku zaistnienia takiego starcia Ukraina nie miałaby większych szans.

Zasadnicze znaczenie dla rosyjskiego zaangażowania w wojnę na Ukrainie wydają się mieć samozwańcze republiki. Pełnią one dla Rosji ważną rolę instrumentu w rozgrywkach międzynarodowych. Ich istnienie pozwala bowiem Federacji Rosyjskiej na oficjalne zdystansowanie się od tego konfliktu i daje możliwość unikania przez to odpowiedzialności za prowadzenie niezgodnych z prawem działań zbrojnych. Moskwa może też występować jako mediator oraz utrzymywać z Ukrainą normalne stosunki ${ }^{43}$. W kontekście tematu niniejszej pracy warto zwrócić uwagę, że to wszystko potęguje wrażenie chaosu, gdyż mamy do czynienia z rozmyciem stanu pokoju i wojny oraz potęgującymi się niejasnościami, kto jest rzeczywistym przeciwnikiem. Można zaryzykować nawet stwierdzenie, że istnienie DRL i ŁRL stanowią główny element hybrydowości tego konfliktu.

Powołanie separatystycznych republik było już wcześniej wykorzystywane przez Federację Rosyjską, m.in. w trakcie konfliktu mołdawskiego czy gruzińskiego ${ }^{44}$, mimo że separatyzmy w tych rejonach powstały niejako w sposób naturalny, bez stymulowania procesu ich rozwoju przez Rosję. Skuteczność działania Federacji Rosyjskiej w ten sposób jest w znacznej mierze wynikiem słabości społeczności międzynarodowej ${ }^{45}$. W świetle wypracowanego dorobku prawa międzynarodowego publicznego istnieją zasady, które pozwalałyby przypisać Rosji działania samozwańczych republik, a w konsekwencji uczynić istniejącą sytuację na Donbasie bardziej klarowną.

W prawie międzynarodowym sprawowanie kontroli przez państwo nad aktorem niepaństwowym pozwala na przypisanie mu odpowiedzialności za jego działania. Orzecznictwo i doktryna międzynarodowe wyróżniają dwa rodzaje kontroli, jakie państwa mogą sprawować wobec danych grup zbrojnych. Pierwszą z nich jest kontrola efektywna. Wspomniał o niej Międzynarodowy Trybunał Sprawiedliwości (MTS) w Hadze w wyroku z 1986 r. w sprawie Nikaragui. MTS rozpatrywał wówczas kwestię odpowiedzialności Stanów

43 A. Legucka, Perspektywa zamrożenia konfliktu w Donbasie, Polski Instytut Spraw Międzynarodowych, „Biuletyn PISM”, 1 III 2017, nr 21, www.pism.pl/publikacje/biuletyn/ nr-21-1463 (dostęp: 5.04.2018).

44 B. Janusz-Pawletta, Separatystyczne dążenia Naddniestrza, Abchazji i Osetii Poludniowej a prawo międzynarodowe, „Bezpieczeństwo Narodowe” 2006, nr 2, s. 100-104.

45 Należy zarazem zauważyć, że społeczność międzynarodowa w latach 90. zajęta kryzysem na Bałkanach po rozpadzie ZSRS upatrywała w Rosji lidera w regionie posowieckich republik. Wydaje się, że inercja innych państw w tym czasie została odebrana przez Federację Rosyjską (zwłaszcza po objęciu rządów przez Putina) jako przyznanie, iż tereny te należą do rosyjskiej strefy wpływów. 
Zjednoczonych za działania partyzantki contras $\mathrm{w}$ tym kraju ${ }^{46}$. W orzeczeniu wskazano, że przypisanie działań grup zbrojnych danemu państwu może wystąpić w przypadku, gdy właśnie to państwo wysłało daną grupę lub działa ona w jego imieniu bądź dokonane przez nie akty poczyniono przy znacznym zaangażowaniu tegoż państwa. Kontrola, jaką państwo ma sprawować, ma mieć charakter ,ścisły i efektywny"47. Niewystarczające w tym względzie jest jedynie wysłanie broni, wsparcie logistyczne, finansowe itp. Państwo musi nadzorować każde działanie takiej grupy.

Stanowisko MTS podzieliła Komisja Prawa Międzynarodowego w komentarzach do swoich Artkułów o odpowiedzialności państw za akty międzynarodowe, wprost nawiązała do orzeczenia w sprawie Nikaragui ${ }^{48}$.

Inny pogląd na te kwestie przedstawił w orzeczeniu Tadić Międzynarodowy Trybunał Karny (MTKJ) ds. zbadania zbrodni w byłej Jugosławii. MTKJ, podobnie jak MTS, uznał za niewystarczające do przypisania danemu państwu operacji zbrojnych aktora niepaństwowego wysyłanie wsparcia finansowego, wyposażenia czy przeprowadzania szkoleń. Kluczowym jest jednak istnienie pewnego stosunku posłuszeństwa i podległości między państwem a daną grupą. Nie jest jednak konieczne nadzorowanie każdego działania danej grupy. Państwo może ograniczyć swoją ingerencję jedynie do aspektu sprawowania ogólnej pieczy i koordynacji nad operacjami danej grupy (tzw. kontrola ogólna) ${ }^{49}$.

Kwestia przypisania odpowiedzialności państwa za działania osób, organów będących pod kierownictwem, kontrolą lub działających według instrukcji państwowych była również przedmiotem rozważań Europejskiego Trybunału Praw Człowieka (ETPCz) w Strasburgu. Wiązało się to z badaniem, gdzie rozciągają się granice jurysdykcji państwa - strony Europejskiej Konwencji Praw Człowieka wobec osoby przebywającej poza jego granicami.

Ta sprawa pojawiła się w kilku orzeczeniach dotyczących kwestii odpowiedzialności Turcji za działania Tureckiej Republiki Północnego Cypru, powstałej w wyniku inwazji armii tureckiej na Cypr w 1974 r. W sprawie Loizidou przeciwko Turcji z 1996 r. wskazano na konieczność uznania tureckiej

46 Orzeczenie Międzynarodowego Trybunału Sprawiedliwości z dn. 27 czerwca 1986, Nicaragua v. United States of America, www.icj-cij.org/en/case/70/judgments (dostęp: 5.04.2018).

47 Ibidem, par. 115.

48 Wskazano również na pogląd wyrażony przez MTKJ w orzeczeniu Tadić, jednakże zaznaczono, że tamta sprawa nie dotyczyła odpowiedzialności państwa, a odpowiedzialności kryminalnej jednostki. Zob. Draft Articles on Responsibility of States for Internationally Wrongful Acts, with Commentaries, ,Text adopted by the International Law Commission at its fifty-third session, in 2001, and submitted to the General Assembly as a part of the Commission's report covering the work of that session (A/56/10)", art. 8, par. 4-5.

Prosecutor v. Duško Tadić..., par. 131-137. 
jurysdykcji państwowej nad terytorium północnego Cypru ze względu na efektywną kontrolę, jaką Turcja tam sprawowała, co zdaniem Trybunału było prostą konsekwencją skali zaangażowanych tam żołnierzy tureckich ${ }^{50}$. W orzeczeniu Cypr przeciwko Turcji z 2001 r. stwierdzono z kolei, że „odpowiedzialność Turcji nie ograniczała się do aktów własnych żołnierzy lub urzędników w północnym Cyprze, lecz powstawała także poprzez akty administracji lokalnej, która przetrwała dzięki wojskowemu i innemu wsparciu Turcji" ${ }^{51}$.

W kontekście tematu artykułu za istotne należy uznać także wyroki w sprawach Ilascu i inni przeciwko Moldawii i Rosji z 2004 r. oraz Catan i inni przeciwko Mołdawii i Rosji z 2012 r. W pierwszym z nich uznano, że państwo wykonuje pełną kontrolę nad danym terytorium przejętym w wyniku zbrojnej operacji. $Z$ tego tytułu na danym państwie spoczywa obwiązek zapewnienia przestrzegania ETPCz niezależnie od tego, kto sprawuję tę kontrolę w jego imieniu ${ }^{52}$. W drugiej sprawie Trybunał wskazał, że jeśli współpraca z reżimem separatystycznym przez wsparcie militarne, finansowe i polityczne jest na tyle silna, że nie jest on w stanie bez tej pomocy przetrwać, to powoduje to, iż państwo wspierające odpowiada za akty dokonywane przez ten reżim. Trybunał uznał również, że w latach 2002-2004 taki przypadek stanowiła Rosja i Naddniestrze ${ }^{53}$.

W obydwu wymienionych orzeczeniach Rosji przypisano odpowiedzialność za działania władz Naddniestrza prowadzących do naruszeń Konwencji. W sprawie Catan i inni przeciwko Mołdawii i Rosji strona rosyjska podnosiła argumenty, powołując się przy tym na orzeczenie MTS, do którego odwoływał się zresztą sam ETPCz, czyli wyrok w sprawie z 2007 r. między Bośnią i Hercegowiną a Serbią i Czarnogórą o zastosowanie konwencji przeciwko ludobójstwu, gdzie stwierdzono konieczność przypisania, gdy „faktycznie te osoby, grupy osób lub organy działają w całkowitej zależności od tego państwa, stanowiąc jedynie jego instrument" ${ }^{\prime 4}$. Z kolei zdaniem Rosji nie można uznać, żeby władze Naddniestrza podlegały aż takiemu stopniowi kon-

50 Loizidou v. Turkey, Application no. 40/1993/435/514, ECHR, 23 February 1995, par. 56

51 Cyprus v. Turkey, Application no. 25781/94, ECHR, 10 May 2001, par. 77; M. Balcerzak, Odpowiedzialność państwa-strony Europejskiej konwencji o ochronie praw człowieka i podstawowych wolności: studium prawnomiędzynarodowe, TTNOiK. Dom Ogranizatora, Torun 2013, s. 165.

52 Ilascu and others v. Moldova and Russia, Application no. 48787/99, ECHR, 8 July 2004, par. 314 i nast.; K. Wierczyńska, Odpowiedzialność państwa za ekstraterytorialne naruszenia prawa międzynarodowego w świetle decyzji i orzeczeń ETPCz, „Europejski Przegląd Sądowy", VI 2008, s. 32.

53 Catan and others v. Moldova and Russia, Application no. 43370/04, 8252/05, 18454/06, European Court of Human Rights, 19 October 2012 r., par. 122.

54 Application of the Convention on the Prevention and Punishment of the Crime of Genocide, Bosnia and Herzegovina v. Serbia and Montenegro, ICJ Reports 2007, par. 392. 
troli. Trybunał odciął się jednak od kwestii przypisania odpowiedzialności na gruncie prawa międzynarodowego, wskazując, że jego rolą jest jedynie wykazanie jurysdykcji w rozumieniu art. 1 ETPC $^{55}$.

Jeżeli przyjrzymy się relacjom między wojskami separatystycznymi, to należy stwierdzić, że stopień kontroli rosyjskiej był różny w zależności od etapu konfliktu.

Do drugiej połowy sierpnia 2014 r., czyli momentu przekroczenia przez regularne jednostki rosyjskich sił zbrojnych idących na pomoc walczącym z ofensywą ukraińską separatystom, zaangażowanie Moskwy na Donbasie nie było zbyt dobrze widoczne, co jeszcze podkreślało wrażenie niejasności co do zaangażowania Rosji w tym konflikcie. Gdy w kwietniu 2014 r. na obszarach obwodu ługańskiego i donieckiego lokalne bojówki zaczęły zajmować, a następnie okupować budynki, wiele mogło wskazywać na samoczynne powstanie, a nie operację zbrojną sterowaną z zewnątrz. Obraz ten jednak zaburzała dostępność do broni rebeliantów, w tym artylerii ciężkiej i czołgów. $\mathrm{Z}$ czasem ten arsenał powiększył się na tyle, że zaczął on być porównywany z zasobami niektórych europejskich państw. Część tego sprzętu pozyskiwano z zajętych podczas działań zbrojnych arsenałów (sui generis łupy wojenne). Przykładem jest tutaj kazus 25. Samodzielnej Brygady Powietrznodesantowej, która wysłana do thumienia rebelii poddała się bez walki. W pozostałych przypadkach rodzaj i miejsce produkcji wykorzystanego przez separatystów sprzętu wskazują jednoznacznie na Federację Rosyjską ${ }^{56}$.

Rosja nie zaprzecza, że jej obywatele angażują się w walki na terytorium Ukrainy. Z tym zastrzeżeniem, że Moskwa nie poczuwała się do brania odpowiedzialności za tych ludzi, twierdząc, że chodzi tu o ochotników, którzy na własną rękę włączyli się w ten konflikt, a nie żołnierzy czy funkcjonariuszy państwowych ${ }^{57}$.

W rzeczywistości jednak poza wspomnianymi ochotnikami, chcącymi wspierać prorosyjski separatyzm na Ukrainie, w szeregach sił separatystycznych znalazło się też wielu czynnych bądź byłych funkcjonariuszy rosyjskich służb specjalnych. Formalnie byli to rezerwiści lub urlopowani, lecz

55 Zdaniem dr. hab. Michała Balcerzaka stanowisko to jest bardzo kontrowersyjne. Kuriozalne -jego zdaniem - jest przywoływanie orzecznictwa MTS odwołującego się do efektywnej kontroli i Artykułów KPM, co robił ETPCz bez wyraźnego potrzeby. Tym bardziej że Trybunał używał pojęcia kontroli efektywnej bez nadawania mu, chociażby na potrzeby działań ETPCz, nowego znaczenia. Zob. M. Balcerzak, Odpowiedzialność państwa..., s. 166-168.

56 C. Kosior, Potencjal militarny Ukrainy...

577 tys. żotnierzy rosyjskich w Donbasie. ,,Sa także oficerowie”, TVN24, www.tvn24.p1/wiadomosci-ze-swiata,2/7-tys-zolnierzy-rosyjskich-w-donbasie,617511.html (dostęp: 5.04.2018). 
zachowali oni związki z dawnymi zwierzchnikami ${ }^{58}$. Najbardziej znanym przedstawicielem tej grupy był Igor Grikin vel Igor Striełkow, pułkownik rezerwy rosyjskiej Federalnej Służby Bezpieczeństwa (FSB), jeden z głównych dowódców sił donbaskich separatystów ${ }^{59}$.

Igor Grikin-Striełkow długo uchodził za najważniejszego przedstawiciela Rosji w separatystycznych republikach. Jego historia może świadczyć też o tym, że osoby o takim jak on statusie miały na tym obszarze sporą swobodę i pełniły funkcje nadzorcze wobec rebeliantów ${ }^{60}$. Celem było usunięcie z tych struktur (włącznie z fizyczną likwidacją) wszystkich niepokornych wobec Federacji Rosyjskiej dowódców ${ }^{61}$. W rezultacie Rosja znacznie umocniła swoją kontrolę nad siłami separatystycznymi ${ }^{62}$.

Zmiany wzmacniające rosyjskie wpływy poczyniono również w strukturze armii Noworosji. Od 2015 r. jest ona ściśle wzorowana na armii rosyjskiej. Od szczebla batalionu wzwyż komenda nad rebelianckimi oddziałami przyznana jest rosyjskim oficerom, co umożliwia już koordynacje rosyjskiemu dowództwu działań nawet poszczególnych oddziałów, a rola separatystów sprowadza się jedynie do roli wykonawców. Ponadto wsparcie Rosji nie ogranicza się tam tylko do kwestii sprzętowych czy logistycznych, ale również Rosjanie dostarczają informacji wywiadowczych, zapewniają rozpoznanie, łączność oraz wspomnianą wcześniej obsługę specjalistycznego sprzętu. Wskazuje się także, że udział obywateli rosyjskich w armii Noworosji sięga już aż $80 \%{ }^{63}$.

Wpływ Moskwy na sytuację na Donbasie nie ogranicza się jedynie do kwestii militarnych. Wsparcie przez Rosję budżetu DRL jest szacowane $70-90 \%$, nie wliczając w to dostaw dla donieckiego wojska. Pomoc rosyjska przejawia się także w zapewnieniu republikom gazu i paliwa, bez których ciężko wyobrazić sobie istnienie tych parapaństw ${ }^{64}$.

58 Russia and the Separatists in Eastern Ukraine, Crisis Group Europe and Central Asia Briefing, No. 79, 5 February 2016, www.crisisgroup.org/en/regions/europe/ukraine/ b079-russia-and-the-separatists-in-eastern-ukraine.aspx, s. 6-10 (dostęp: 5.04.2018).

59 G. Kuczyński, Własne KGBi , Beria z Naddniestrza”. Już wiadomo, co Rosja planuje w Donbasie?,TVN24, www.tvn24.pl/wiadomosci-ze-swiata,2/wlasne-kgb-i-beria-z-naddniestrza-juz-wiadomo-co-rosja-planuje-w-donbasie,451803.html (dostęp: 5.04.2018).

60 „Bohater Noworosji” rezygnuje. Strietkow juz nie jest szefem obrony Donbasu, TVN24, www.tvn24.pl/wiadomosci-ze-swiata,2/bohater-noworosji-rezygnuje-strielkow-juz-nie-jest-szefem-obrony-donbasu,459093.html (dostęp: 5.04.2018).

61 „Polowanie” w Donbasie. Lider rebeliantów ,'ścigany przez rosyjskie stużby specjalne”, TVN24, www.tvn24.pl/wiadomosci-ze-swiata,2/sbu-ujawnia-rosyjskie-sluzby-likwiduja-dowodcow-rebeliantow,547597.html (dostęp: 5.04.2018).

62 C. Kosior, Potencjal militarny Ukrainy...

63 Ibidem.

64 Russia and the Separatists..., s. 7-8. 
Warto także przypomnieć, że to rosyjska interwencja wojskowa uratowała separatystyczne republiki przed unicestwieniem latem 2014 r. Armia ukraińska od końca czerwca do drugiej połowy sierpnia 2014 r. zdołała odbić z rąk rebeliantów niemal całość terytorium obwodów donieckiego i ługańskiego. Ofensywa załamała się dopiero po wkroczeniu sił rosyjskich. Ponadto w czasie innych starć między siłami rządowymi a separatystami wojska rosyjskie uniemożliwiały załamanie się rosyjskiej obrony.

Pewną ilustracją, jak dużą kontrolę Rosja sprawuje nad oddziałami separatystów, może być fakt, że nasilenie bądź zaprzestanie walk na Donbasie jest nierzadko związane z konkretnymi krokami podejmowanymi przez Rosję na arenie międzynarodowej ${ }^{65}$. Mimo też negacji przez Moskwę obecności na Donbasie, jest ona uznawana przez znaczną część społeczności międzynarodowej za czynnik determinujący rozwój sytuacji. Konsekwencją tego są m.in. wprowadzone sankcje przeciw Rosji za zaangażowanie w tę wojnę oraz jej udział w rozmowach na temat zakończenia tego konfliktu.

Oczywiście obecny, najściślejszy stopień związania Donieckiej Republiki Ludowej i Ługańskiej Republiki Ludowej z decyzjami Moskwy został osiągnięty dopiero po pewnym czasie. Kontrola rosyjska nasiliła się w szczególności po porozumieniach mińskich. Wcześniej jednak usadowienie funkcjonariuszy GRU i FSB na kluczowych stanowiskach w ludowych republikach zapewniało odpowiednią koordynację działań, gdzie zbyt duże przejawy swobody były eliminowane.

Można zatem uznać, że Rosja do lutego 2015 r. sprawowała nad rebeliantami kontrolę ogólną, natomiast po zawarciu drugiego porozumienia mińskiego, czyli od marca 2015 r., coraz bardziej była ona już zbliżona do kontroli efektywnej.

Warto również zwrócić uwagę na to, że wsparcie Rosji dla separatystycznych republik ma zasadnicze znaczenie, gdyż nie są one w stanie samodzielnie się utrzymać. Skala wsparcia finansowego, materialnego oraz zaangażowanie

65 Na przykład przed rozmowami w Mińsku w sprawie implementacji przepisów rozejmu 20 stycznia 2016 r. OBWE zaobserwowało wzmożoną aktywność separatystów, natomiast jednym $\mathrm{z}$ najspokojniejszych dni w poprzednim roku był 1 września, kiedy to prezydent Rosji Władimir Putin przemawiał przed Zgromadzeniem Ogólnym ONZ. Zob. Latest from OSCE Special Monitoring Mission (SMM) to Ukraine, based on information received as of 19:30hrs, 20 January 2016, Organisation of Security and Cooperation in Europe, www.osce.org/ukraine-smm/217766 (dostęp: 5.04.2018); Latest from OSCE Special Monitoring Mission (SMM) to Ukraine based on information received as of 1 September 2015, Organisation of Security and Cooperation in Europe, http://www.osce. org/ukraine-smm/179706 (dostęp: 5.04.2018). 
wojska jest na tyle duża, że skłania to, biorąc pod uwagę wspomniane już orzecznictwo ETPC, do stwierdzenia, że Rosja w pewnym stopniu odpowiada za działania wojska i administracji republik.

Wydaje się, że z punktu prawa międzynarodowego nie zachodzą raczej przeszkody, aby Rosję uznać za stronę konfliktu zbrojnego z Ukrainą. Parlament ukraiński niedawno wprawdzie uznał Federację Rosyjską za agresora, jednak nadal nie postępuje zgodnie z normami mającymi zastosowanie w przypadku konfliktów międzynarodowych (np. uznanie statusu jeńca wojennego wobec wojsk prorosyjskich). Dopiero konsekwentnie traktowanie obszaru separatystycznych republik jako terenów okupowanych oraz sił donieckich i ługańskich jako część rosyjskich sił zbrojnych pozwoli na zniwelowanie najgroźniejszych dla Ukrainy skutków hybrydowości tego konfliktu ${ }^{66}$.

\section{Podsumowanie}

Trwający od końca lutego 2014 r. konflikt zbrojny między Ukrainą a Rosją można uznać za modelowy przykład wojny hybrydowej. Rosja, którą ze względu na swoje zaangażowanie i stopień sprawowanej kontroli nad samozwańczymi republikami można postrzegać jako stronę konfliktu, wykorzystała całą różnorodność hybrydowych metod. Utworzenie separatystycznych republik umożliwiło przede wszystkim wyparcie swojej odpowiedzialności za zaangażowanie w ten konflikt. Jest to klasyczny przykład wojny przez pośrednika.

Elementy hybrydowe były widoczne również na początku tego konfliktu ${ }^{67}$, w trakcie operacji krymskiej, gdy państwo to wykorzystywało w działaniach zbrojnych niemal wyłącznie własne siły zbrojne. Wówczas jednak Rosjanie, chcąc uniknąć przypisania odpowiedzialności za te działania, wykorzystali żołnierzy w mundurach bez oznaczeń. Był to pretekst, za którego pomocą, poza wspomnianym wyparciem się odpowiedzialności, wprowadzano w błąd społeczność międzynarodową co do oceny sytuacji na tym obszarze.

66 Warto zaznaczyć, że od tej kwestii należałoby oddzielić sprawę formalnego wypowiedzenia wojny Rosji. Postulat ten co jakiś czas pojawia się w ukraińskim dyskursie publicznym. Jednakże zdecydowanie się na taki krok ze strony władz w Kijowie mogłoby doprowadzić do nadmiernej eskalacji konfliktu. Szerzej na ten temat: P. Ochmann, J. Wojas, Współczesne znaczenie aktu wypowiedzenia wojny..., s. 93-105.

67 Odrębnym zagadnieniem, nad którym można by się zastanawiać, jest kwestia, czy wydarzenia na Donbasie stanowią kontynuację konfliktu zapoczątkowanego na Krymie, czy też można by je uważać za dwa odrębne konflikty. Analiza tego zagadnienia wykracza jednak poza ramy artykułu. 
Na dalszym etapie wojny wojska rosyjskie również kamuflowały swoją obecność, mimo że ciężar walki skupił się na oddziałach separatystycznych, które wykorzystywały działania o charakterze dywersyjnym i partyzanckim.

Obecnie działania zbrojne prowadzone na ograniczonym obszarze wschodniej i południowo-wschodniej Ukrainy stanowią kryterium pozwalające zakwalifikować sytuację jako wojnę hybrydową, prowadząc do stanu rozmycia między stanem pokoju i stanem wojny. Tym bardziej że konflikt kilkukrotnie przechodził fazy wzmożenia i osłabienia działań zbrojnych, stając się wówczas konfliktem zamrożonym.

Jednocześnie jednak dzięki wypracowanym na gruncie prawa międzynarodowego regułom, możliwe zdaje się być przypisanie odpowiedzialności Rosji za działania separatystycznych republik. Uznanie i traktowanie Federacji Rosyjskiej za stronę konfliktu zbrojnego przez Ukrainę zniwelowałoby wiele negatywnych konsekwencji wprowadzanych przez Moskwę elementów hybrydowych, a sam konflikt przez pełne zastosowanie do niego norm prawa humanitarnego przewidzianych dla konfliktów międzynarodowych byłby trudny do zanegowania przez Federację Rosyjską. Ukraina wzbrania się jednak przed nazwaniem zaistniałych wydarzeń mianem wojny i posługuje się terminem ,operacja antyterrorystyczna”. Wynikać to może z obawy przed eskalacją konfliktu, którego pod względem militarnym państwo ukraińskie nie miałoby najmniejszych szans wygrać. Zakwalifikowanie takie mogłoby być także pod pewnymi względami niewygodne dla Ukrainy, gdyż oznaczałoby konieczność traktowania pojmanych separatystów jako jeńców wojennych, w przeciwieństwie do obecnej praktyki, gdy są oni uznawani za kryminalistów. Taki status pociągałby za sobą zupełnie odmienny reżim prawny ${ }^{68}$.

\section{Bibliografia}

„Bohater Noworosji” rezygnuje. Striełkow już nie jest szefem obrony Donbasu, TVN24, www. tvn24.pl/wiadomosci-ze-swiata,2/bohater-noworosji-rezygnuje-strielkow-juz-nie-jestszefem-obrony-donbasu,459093.html.

„Polowanie” w Donbasie. Lider rebeliantów „ścigany przez rosyjskie stużby specjalne”, TVN24, www.tvn24.pl/wiadomosci-ze-swiata,2/sbu-ujawnia-rosyjskie-sluzby-likwidujadowodcow-rebeliantow, 547597.html.

Balcerzak M., Odpowiedzialność państwa-strony Europejskiej konwencji o ochronie praw człowieka i podstawowych wolności: studium prawnomiędzynarodowe, TTNOiK. Dom Ogranizatora, Torun 2013.

68 Pomijamy w tym miejscu przez takie postępowanie kwestię przestrzegania przez państwo ukraińskie praw człowieka, gdyż zagadnienie to z całą pewnością wykracza poza ramy artykułu. 
Bierzanek R., Symonides J., Prawo międzynarodowe publiczne, Wydawawnictwo Prawnicze LexisNexis, Warszawa 2004.

Burlakowa W., Nestrašnyj sud. Kak ukrainskaâ Femida 'karaet separatistov, Antikor, http://antikor.com.ua/articles/68825-nestrashnyj_sud._kak_ukrainskaja_femida_karaet_separatistov.

Dramatycznystenogramws. Krymu.,,Myich wyślemynaśmierć,, WirtualnaPolska, https://wiadomosci. wp.pl/dramatyczny-stenogram-ws-krymu-my-ich-wyslemy-na-smierc-6025262095110785a.

Gawęda M., Sity Zbrojne „,Noworosji”. W kierunku zwasalizowanej armii regularnej, Defence24, www.defence24.pl/185935,sily-zbrojne-noworosji-w-kierunku-zwasalizowanej-armiiregularnej.

GPU obnarodovala zapisi telefonny h razgovorov sovetnika prezidenta RF Glaz 'eva otnositel'no pla$n a$, ,Novorossiâ”, 112ua, https://112.ua/glavnye-novosti/gpu-obnarodovala-zapisi-telefonnyh-razgovorov-sovetnika-prezidenta-rf-glazeva-otnositelno-plana-novorossiya--333576.html.

Hoffman F.G., Conflict in the 21st Century: The Rise of Hybrid Wars, Potomac Institute for Policy Studies, Arlington, VA 2007.

Hoffman F.G., Lessons from Lebanon: Hezbollah and Hybrid Wars, Foreign Policy Research Institute, www.fpri.org/article/2006/08/lessons-from-lebanon-hezbollah-and-hybrid-wars.

Hoffman F.G., On Not-So-New Warfare: Politicale Warfare vs. Hybrid Threats, https://warontherocks.com/2014/07/on-not-so-new-warfare-political-warfare-vs-hybrid-threats/.

Janusz-Pawletta B., Separatystyczne dążenia Naddniestrza, Abchazji i Osetii Poludniowej a prawo międzynarodowe, „Bezpieczeństwo Narodowe” 2006, nr 2.

Kleczkowska A., Wojna hybrydowa - uwagi z perspektywy prawa międzynarodowego publicznego, „Sprawy Międzynarodowe” 2015, nr 2.

Konończuk W., Wilk A., Eskalacja starć w Donbasie, Ośrodek Studiów Wschodnich, www. osw.waw.pl/pl/publikacje/analizy/2015-01-21/eskalacja-starc-w-donbasie.

Kosior C., Potencjat militarny Ukrainy wobliczu rosyjskiej agresji, Ośrodek Analiz Strategicznych, https://oaspl.org/2015/06/23/potencjal-militarny-ukrainy-w-obliczu-rosyjskiej-agresji.

Kozacy ogłaszaja nowa republikę na wschodzie Ukrainy. Atakują sity rzadowe, sa zabici i ranni, „Gazeta Wyborcza”, http://wyborcza.p1/1,76842,16809315,Kozacy_oglaszaja_nowa republike_na_wschodzie_Ukrainy_html.

Kraj K., Wojny asymetryczne czy miatiė̇ewojna Jewgienija Messnera zagrożeniem dla bezpieczeństwa w XXI wieku, „Bezpieczeństwo. Teoria i Praktyka” 2012, nr 3.

Kubiak K., RAPORT-wto 04/2014 - Utrata Krymu, Raport Wojsko - Technika - Obronność, www.altair.com.pl/magazines/article?article_id=5150.

Kuczyński G., Własne KGB i „Beria z Naddniestrza”. Już wiadomo, co Rosja planuje w Donbasie?, TVN24, www.tvn24.pl/wiadomosci-ze-swiata,2/wlasne-kgb-i-beria-z-naddniestrzajuz-wiadomo-co-rosja-planuje-w-donbasie,451803.html.

Legucka A., Perspektywa zamrożenia konfliktu w Donbasie, Polski Instytut Spraw Międzynarodowych, „Biuletyn PISM”, 1 III 2017, nr 21, www.pism.pl/publikacje/biuletyn/nr-21-1463.

Media freedom situation in Crimea, Ukraine, at all-time low, OSCE Representative says, Organisation for Security and Co-operation in Europe, www.osce.org/fom/143861.

Menkiszak M., Sadowski R., Żochowski P., Rosyjska interwencja zbrojna we wschodniej Ukrainie, Ośrodek Studiów Wschodnich, www.osw.waw.pl/pl/publikacje/ analizy/2014-09-03/rosyjska-interwencja-zbrojna-we-wschodniej-ukrainie.

Miesnier J.E., Wsiemirnaja miatieżewojna, Żukowskij-Moskwa 2004.

Mikulska M., Separatystyczne republiki na Ukrainie uznane za organizacje terrorystyczne, „Rzeczpospolita", www.rp.pl/artykul/1110516-Separatystyczne-republiki-na-Ukrainie-uznane-za-organizacje-terrorystyczne.html. 
Ochmann P., Wojas J., Wspótczesne znaczenie aktu wypowiedzenia wojny w kontekście konfliktu na wschodzie Ukrainy, „Sprawy Międzynarodowe” 2015, nr 4.

Parlament Ukrainy uchwalit ustawę o reintegracji Donbasu. „,Rosja agresorem”, bankier.pl, www.bankier.pl/wiadomosc/Parlament-Ukrainy-uchwalil-ustawe-o-reintegracji-Donbasu-Rosja-agresorem-4016852.html.

Petna gotowość bojowa w ,, donieckiej republice”. Bunt Kozaków przyspieszy wojnę?, TVN24, www.tvn24.pl/wiadomosci-ze-swiata,2/donbas-mobilizacja-rebeliantow-oddzialy-wpelnej-gotowosci-bojowej,531592.html.

Piechal T., Republiki wojenne w Donbasie rok po wybuchu konfliktu, Ośrodek Studiów Wschodnich, www.osw.waw.pl/pl/publikacje/komentarze-osw/2015-06-17/republiki-wojenne-w-donbasie-rok-po-wybuchu-konfliktu.

Regina-Zacharski J., Analityczne definicje wojny, „Studia Geopolitica”2010/2011, R. 1, http:// geopolityka.org/analizy/jacek-reginia-zacharski-analityczne-definicje-wojny.

Regina-Zacharski J., Ukraina 2014-2015: wojna (nie)hybrydowa, „Zeszyty Naukowe AON” 2015, vol. 100, nr 3.

Russia and the Separatists in Eastern Ukraine, Crisis Group Europe and Central Asia Briefing, No. 79, 5 February 2016, www.crisisgroup.org/en/regions/europe/ukraine/b079-russia-and-the-separatists-in-eastern-ukraine.aspx.

Srogosz T., Status prawny nieoznakowanych żolnierzy $w$ wojnie hybrydowej, „Sprawy Międzynarodowe" 2015, $\mathrm{nr} 4$.

Sun Tzu, Sun Pin, Sztuka wojny, thum. D. Bakalarz, Helion, Gliwice 2004.

Sykulski L., Wojny buntownicze - wprowadzenie do koncepcji Jewgienija Messnera, „Przegląd Geopolityczny" 2015, nr 11.

Ukraina apeluje o uznanie separatystycznych republik za organizacje terrorystyczne, Telewizja Republika, http:/telewizjarepublika.pl/ukraina-apeluje-o-uznanie-separatystycznych-republik-za-organizacje-terrorystyczne, $15952 . \mathrm{html}$.

Ukraina: rossijskie vojska tak i ne ušli iz-pod Hersona, BCC News Russian www.bbc.com/ russian/international/2014/12/141210_russian_military_kherson.

W „Ługańskiej Republice Ludowej” narasta bunt. Apelują do Rosji, by „zrobiła porzadek”, TVN24, www.tvn24.pl/wiadomosci-ze-swiata,2/w-luganskiej-republice-ludowej-narasta -bunt-kozacy-apeluja-do-wladimira-putina,503690.html.

Wąsowski K., Istota i uniwersalność rosyjskiego modelu wojny hybrydowej, „Sprawy Międzynarodowe" 2015, nr 2.

Wierczyńska K., Odpowiedzialność państwa za ekstraterytorialne naruszenia prawa międzynarodowego w świetle decyzji i orzeczeń ETPCz, „Europejski Przegląd Sądowy”, VI 2008.

Wilk A., Ukraińska operacja antyterrorystyczna w Kramatorsku i Słowiańsku - gra pozorów?, Ośrodek Studiów Wschodnich, www.osw.waw.pl/pl/publikacje/analizy/2014-05-08/ ukrainska-operacja-antyterrorystyczna-w-kramatorsku-i-slowiansku-gra.

Wilk A., Olszański T.A., Górecki W., Porozumienie mińskie - rok gry pozorów, www.osw.waw. $\mathrm{pl} / \mathrm{pl} / \mathrm{publikacje} /$ analizy/2016-02-10/porozumienie-minskie-rok-gry-pozorow.

Willisamson Murray M., Mansoor P.R., Hybrid Warfare: Fighting Complex Opponets from the Ancient World to the Present, Cambridge University Press, Cambridge 2012. 